\title{
PERBANDINGAN SEGMENTASI PADA CITRA ASLI DAN CITRA KOMPRESI WAVELET UNTUK IDENTIFIKASI TELUR
}

\author{
Anton Yudhana ${ }^{1}$, Sunardi ${ }^{2}$, Shoffan Saifullah ${ }^{3}$ \\ 1eyudhana@mti.uad.ac.id, ${ }^{2}$ sunardi@mti.uad.ac.id, 3shoffan_s@yahoo.com \\ 1,2Teknik Elektro, Universitas Ahmad Dahlan \\ ${ }^{3}$ Magister Teknik Informatika, Universitas Ahmad Dahlan
}

\begin{abstract}
Abstrak
Citra digital merupakan gambaran yang jelas dari objek yang dapat diolah dengan komputer. Semakin besar ukuran (pixel) citra akan membutuhkan tempat penyimpanan yang besar pula. Dasar pengolahan citra yang dilakukan dalam penelitian ini terletak pada proses segmentasi pengolahan citra. Hal yang perlu dipertimbangkan adalah objek dari citra telur ayam yang akan diidentifikasi. Proses pengolahan citra melibatkan beberapa proses mulai dari akuisisi citra, preprocessing dan proses pengolahan citra sampai hasilnya. Preprocessing dilakukan untuk proses segmentasi yaitu dengan mengubah citra menjadi citra grayscale, dan kemudian diubah menjadi citra hitam putih. Dalam setiap proses dilakukan padding haar untuk mengurangi ukuran (size on disk) dengan matrik haar $8 \times 8$. Dan juga dilakukan proses dilasi dan opening untuk membuat objek terlihat jelas serta menghaluskan permukaan untuk menghilangkan noise. Pada proses pengolahannya dilakukan dengan menggunakan segmentasi dan pelabelan dengan didahului dengan perhitungan centroid dan penentuan bounding box untuk mengidentifikasi telur ayam. Perbandingan hasil pengolahan citra asli dengan hasil kompresi dari citra asli menunjukkan bahwa proses segmentasi citra telur ayam memberikan hasil $100 \%$ sama (baik citra asli maupun citra kompresi wavelet). Dengan kompresi akan menghemat penyimpanan (disk) dan hasil yang sama diperoleh dalam proses perhitungan objek, luas area, dan penentuan titik centroid.
\end{abstract}

Kata kunci: kompresi wavelet, padding haar, segmentasi dan labelling, centroid dan bounding box.

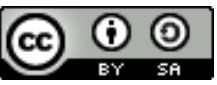

ILKOM Jurnal IImiah work is licensed under a CCA-SA 4.0 International License.

\section{Pendahuluan}

Pengolahan citra dari objek telur ayam sudah banyak dilakukan. Proses pengolahan citra telur ayam dengan menggunakan metode statistik orde pertama digunakan untuk mengidentifikasi telur ayam[1],[2]. Pengidentifikasian dilakukan dengan memperhatikan beberapa faktor misalnya kebersihan kerabang telur ayam dan dilakukan proses pengolahan lanjut dengan menggunakan metode statistik orde kedua untuk ekstraksi ciri telur ayam, serta dilakukan pengelompokan dengan metode K-Nearest Neightboar (KNN) dengan tingkat keberhasilan 88.89\%[1]. Perbedaan bentuk fisik dan warna telur juga menjadi faktor untuk melakukan identifikasi telur ayam. Berdasarkan pada bentuk fisik dan warna telur yang dilakukan pengolahan citra dengan beberapa metode yaitu pengubahan nilai keabuan, peningkatan kontras citra, penapisan dengan filter gaussian, ekualisasi histogram, segementasi thresholding otsu, dan kemudian proses segmentasi mampu membedakan telur dengan perbedaan nilai statistik[2]. Dalam pengolahan citra, pencitraan objek telur ayam dapat dilakukan dengan menggunakan web camera. Proses klasifikasi ukuran telur ayam dan penentuan bobot dilakukan dengan pengolahan citra menggunakan metode segmentasi. Proses klasifikasi telur ayam dengan 36 sempel memberikan hasil 100\% tingkat keakurasian, sementara penentuan bobot hanya memberikan hasil $42 \%$ tingkat keakurasian[3].

Identifikasi telur juga dapat dilakukan dengan menggunakan mendeteksi fertilitas telur berdasarkan pada embrio yang ada dalam telur[4],[5],[6],[7]. Proses deteksi telur dilakukan dengan menggunakan metode thresholding dengan nilai 50 mampu mendetaksi telur berembrio, tapi telur rusak mampu dideteksi dengan hasil $91.7 \%$ tingkat keakurasiannya[4]. Identifikasi telur ayam juga dapat dilakukan dengan menggunakan thermal imaging camera untuk proses akuisisi citranya[5],[6]. Thermal Imaging merupakan suatu teknik menggunakan energi inframerah yang tidak terlihat kasat mata, dipancarkan oleh obyek dan diubah menjadi gambar panas secara visual[8]. Identifikasi telur dilakukan dengan menggunakan beberapa metode yaitu kurva dingin, daerah dingin, perkembangan, bentuk oval dan morfologi dari telur, serta ekstraksi telur ayam dengan Region of Interest (ROI) [5],[7] dengan hasil bahwa telur tidak dibuahi waktu 4 hari adalah $89.6 \%$, dan embrio telur dalam 16 hari adalah $96.3 \%$ dari keseluruhan[5]. Dan identifikasi dan filtering telur yang fertile dapat dilakukan dengan menggunakan operator sobel, teori fuzzy dan atmriks co-occurrence yang mampu 
memproses dengan keakurasian sistem mencapai 96\% dan kecepatan deteksi 2-3 detik[6]. Selain itu juga dapat dilakukan dengan menggunakan hyperspectral imaging untuk mengetahui fertilitas telur. Ekstraksi ciri dengan menggunakan K-Means dengan hasil klasifikasi telur setiap hari pada proses inkubasi yaitu hari ke-1 sebesar $65,29 \%$, hari ke-2 sebesar $61,18 \%$, sebesar ke-3 yaitu $72,94 \%$, dan hari ke-4 sebesar $84,12 \%$, sehingga perkembangan embrio sulit untuk dideteksi selama 2 hari pertama pada saat telur berada di incubator[7].

Proses segmentasi dengan metode connected component analysis mampu mengklasifikasi telur ayam dan telur puyuh dengan citra background hitam. Klasifikasi dilakukan dengan akurat dan mampu menghitung jumlah telur[9]. Pengenalan telur dapat dilakukan juga menggunakan metode centroid clasifier dan preprocessing menggunakan HSV (Hue, Saturation and Value) dari citra RGB. Hasil klasifikasi menunjukan bahwa telur bebek memiliki ciri rata-rata hue antara 0,089-0,094 dan rata-rata saturasi antara 0,12-0,32. Telur ayam negeri memiliki ciri rata-rata hue antara 0,033-0,053 dan rata-rata saturasi antara 0,52-0,62, sedangkan telur ayam kampung memiliki ciri rata-rata hue antara 0,061-0,068 dan rata-rata saturasi antara 0,21-0,25 [10].

Berdasarkan pada penelitian yang dilakukan, peneliti akan membuat perbedaan dalam proses pengolahan citra dari penggunaan metode, analisis yang dilakukan, maupun menggunakan metodemetode yang telah dilakukan akan tetapi dengan mengkombinasikannya. Dalam penelitian yang dilakukan yaitu menggunakan centroid dan bounding box dalam menentukan obyek dan luas area telur ayam, dan dilkukan perbandingan proses preprocessing, metode yang digunakan, serta hasil dari proses pengolahan citra. Dengan menggunakan metode segmentasi untuk membandingkan citra asli dengan citra kompresi wavelet.

\section{Landasan Teori}

\subsection{Pengolahan Citra}

Citra merupakan sebuah gambaran, kemiripan, atau imitasi dari suatu objek. Citra dapat berupa foto, sinyal video (gambar di TV) atau bersifat digital yang dapat langsung disimpan dalam media penyimpanan. Citra yang dapat diolah oleh komputer disebut citra digital. Setiap citra dapat diperoleh dengan akuisisi citra, yaitu proses yang dilakukan untuk mendapatkan citra digital sampai pencitraan. Pencitraan merupakan cara mengubah citra tampak (foto, gambar, patung, dal lain-lain)[11].

Dalam pengolahan citra diperlukan proses preprocessing yang bertujuan dalam memperbaiki citra dengan meningkatkan kualitas citra dengan pengaturan kontras dan brightness, menghilangkan noise, restorasi citra, transformasi citra, dan menentukan bagian citra yang akan diobservasi. Proses preprocessing salah satunya dengan mengubah citra asli (warna/RGB) menjadi citra abu-abu (grayscale). Nilai intensitas untuk tiap piksel pada citra keabuan merupakan nilai tunggal dimana nilai intensitasnya berada pada interval 0-255, sedangkan pada citra berwarna perlu tiga nilai intensitas yang berada pada interval 0-255 untuk tiap pikselnya. Semakin mendekati nilai 255, maka derajat keabuan akan semakin terang. Pada dasarnya proses ini dilakukan dengan meratakan nilai piksel dari 3 nilai RGB menjadi 1 nilai[11].

\subsection{Histogram ekualisasi}

Histogram ekulisasi merupakan probabilitas statistic distribusi dari setiap tingkat keabuan (grayscale) pda citra digital[12],[13]. Metode digunakan untuk perataan histogram dari citra grayscale, sehingga citra dikelompokkan kedalam level nilai intensitas warna piksel yang berbeda. Citra grayscale 8 bit memiliki 256 level nilai intensitas yang berbeda. Histogram akan ditampilkan kedalam grafik terdistribusi dari masing-masing 256 level nilai pixel tersebut.

\subsection{Opening dan Dilasi}

Operasi opening dan dilasi merupakan bagian dari proses morfologi. Morfologi merupakan suatu teknik pengolahan citra yang didasarkan pada bentuk segmen (daerah citra). Dilasi digunakan untuk memperbesar ukuran segmen di sekitar obyek, dan Opening digunakan untuk memperkecil ukuran citra kemudian baru dilakukan proses dilasi dan berfungsi untuk memperhalus batas objek, memperhalus objek dan menghilangkan noise.

\subsection{Segmentasi}

Segmentasi adalah metode yang digunakan untuk mempartisi/membagi citra menjadi beberapa bagian pokok yang memiliki informasi penting. Pada penelitian ini digunakan untuk mendeteksi objek dengan memisahkan objek dengan background (latar belakang)[11]. Segmentasi pada penelitian ini menggunakan 2 metode yaitu thresholding dan pelabelan. Thresholding yaitu proses segmentasi dari sebuah citra grayscale dengan menghasilkan citra biner. Proses binerisasi memerlukan nilai threshold/ambang (T). Threshold OTSU merupakan algoritma yang digunakan untuk melakukan segmentasi citra digital abu-abu ke dalam citra digital hitam (foreground) dan putih (background). Histogram Thresholding Otsu memberikan sebaran nilai intensitas pada tiap piksel pada citra dalam 1 dimensi. Histogram tersebut berfungsi dalam pengelompokkan piksel-piksel dalam citra didasarkan 
pada nilai threshold. Sehingga untuk mendapatkan hasil maksimal maka nilai threshold harus mampu memisahkan kelas-kelas sehingga nilai intensitas piksel antar kelas berbeda-beda.

\subsection{Region Props}

Region props digunakan untuk membantu dalam proses penetuan nilai centroid dan penentuan daerah bounding box. Centroid digunakan untuk menentukan nilai tengah dari suatu obyek telur yang terdeteksi yang memiliki nilai berdasarkan sumbu $\mathrm{x}$ dan $\mathrm{y}$, dan bounding box merupakan metode yang digunakan untuk menentukan objek dan menandainya dengan kotak yang sesuai besarnya dengan obyek yang teridentifikasi[14].

\subsection{Wavelet}

Wavelet merupakan gelombang singkat yang energinya terkonsentrasi pada selang waktu untuk menganalisis transien, ketidaksioneran, atau perubahan fenomena terhadap waktu. Wavelet digunakan sebagai alat bantu matematis untuk melakukan dekomposisi suatu sinyal (misal audio dan citra) menjadi komponen-komponen frekuensi yang berbeda, sehingga masing-masing komponen tersebut dapat dipelajari dengan menggunakan skala resolusi yang sesuai. Karena itu, wavelet dikenal sebagai alat untuk analisis berdasarkan skala [15].

Discrete Wavelet Transform (DWT) merupakan dekomposisi citra pada frekuensi subband citra tersebut. Komponen sub-band transformasi wavelet dihasilkan dengan cara penurunan level dekomposisi. Implementasi DWT dapat dilakukan dengan cara melewatkan sinyal melalui sebuah level low pass filter (LPF) dan level high pass filter (HPF) dan melakukan down sampling pada keluaran masing-masing filter. DWT selain menggunakan fungsi wavelet, juga menggunakan fungsi skala untuk penghalusan citra (image smoothing) [15].

\section{Metode}

Dalam melakukan proses segmentasi untuk membandingkan citra asli dengan citra kompresinya dilakukan dengan menggunakan metode pengolahan citra seperti pada Gambar 1.(b). Metodologi penelitian secara umum dilakukan seperti pada Gambar 1.(a), dimana proses penelitian memerlukan referensi dari kajian paper terdahulu, penyiapan alat, bahan, dan data yang akan digunakan. Dalam penelitian diperlukan proses analisis dan perancangan atas apa yang akan dilakukan. Pengujian sistem dilakukan dengan menggunakan data-data yang telah didapatkan dan diuji dengan kesesuaian prediksi yang diharapkan. Akan tetapi perlu dilakukan analisis ulang mengenai acuan yang diaharapkan dengan rancangan yang dibuat. Sehingga hasil memberikan nilai maksimal dari pengujian yang dilakukan.

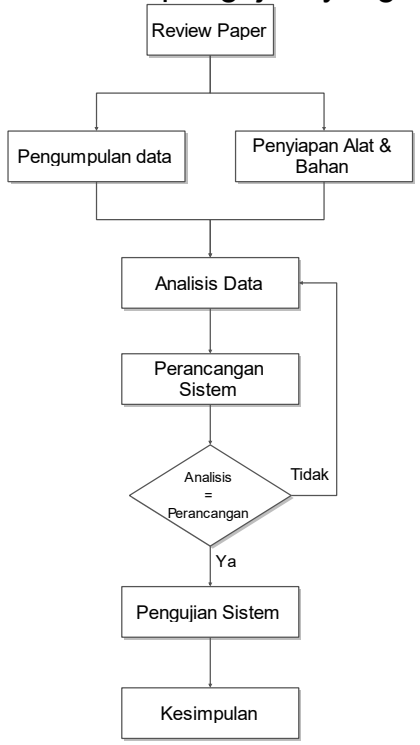

(a)

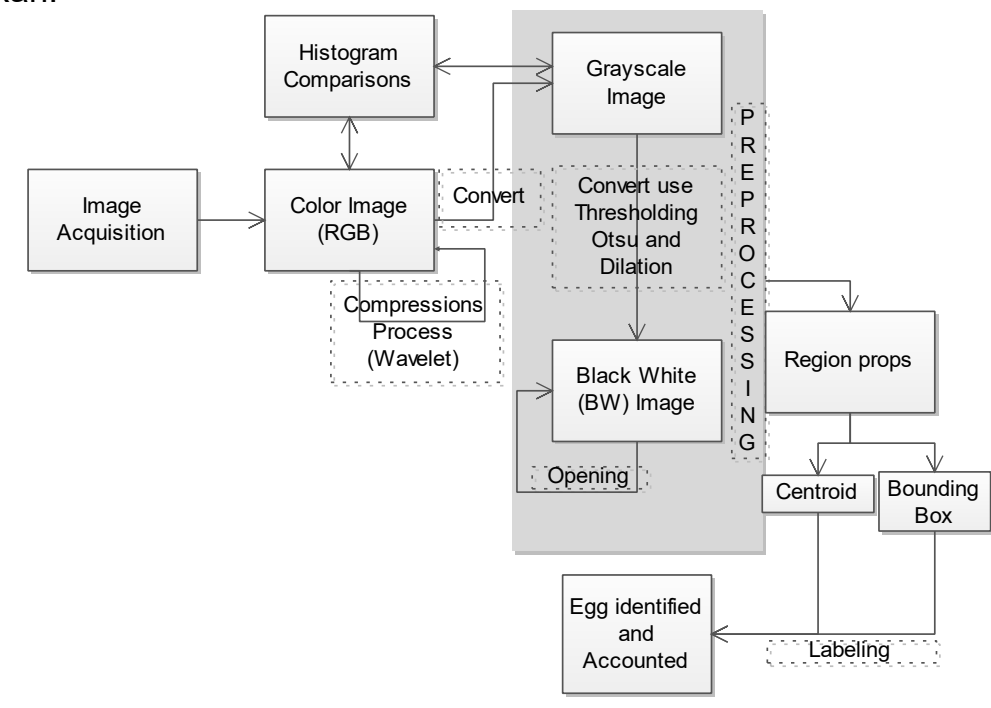

(b)

\section{Gambar 1. Metodologi Penelitian (a) Secara Umum [16], (b). Alur Proses Pengolahan Citra Telur}

Gambar 1 menunjukan proses pengolahan citra mulai dari proses akuisisi citra sampai dengan proses segmentasi untuk menentukan luas area objek telur ayam dan perhitungan titik tengan (centroid) objek telur ayam. Citra yang diakuisisi dengan kamera adalah citra warna (RGB) yang akan dilakukan proses preprocessing (diubah menjadi citra grayscale dan citra hitam putih). Citra warna dilakukan proses kompresi dengan metode wavelet, dan Citra grayscale dilakukan proses perbandingan antra histogram dari citra warna dan grayscale. Berdasarkan perbandingan histogram 
didapatkan bahwa histogram dari citra grayscale memberikan gambar yang lebih rata dan citra grayscale diubah menjadi citra hitam putih dengan menggunakan thresholding otsu dan dilasi. Sebelum dilakukan proses region props, labelling dan perhitungan objek telur ayam citra hitam putih harus dilakukan opening untuk menghaluskan objek dan menghilangkan noise (yang tidak diinginkan).

\section{Hasil}

Matriks Haar 8x8 yang digunakan untuk padding pada gambar Asli yang akan diubah menjadi grayscale dan dilakukan kompresi dengan wavelet.

$\begin{array}{|rrrrrrrr|}0,3536 & 0,3536 & 0,5 & 0 & 0,7071 & 0 & 0 & 0 \\ 0,3536 & 0,3536 & 0,5 & 0 & -0,7071 & 0 & 0 & 0 \\ 0,3536 & 0,3536 & -0,5 & 0 & 0 & 0,7071 & 0 & 0 \\ 0,3536 & 0,3536 & -0,5 & 0 & 0 & -0,7071 & 0 & 0 \\ 0,3536 & -0,3536 & 0 & 0,5 & 0 & 0 & 0,7071 & 0 \\ 0,3536 & -0,3536 & 0 & 0,5 & 0 & 0 & -0,7071 & 0 \\ 0,3536 & -0,3536 & 0 & -0,5 & 0 & 0 & 0 & 0,7071 \\ 0,3536 & -0,3536 & 0 & -0,5 & 0 & 0 & 0 & -0,7071\end{array} \mid$

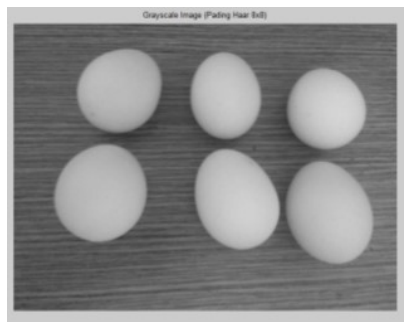

(a)

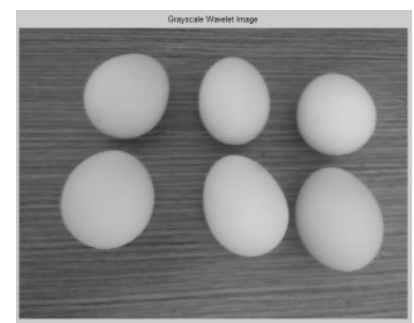

(b)

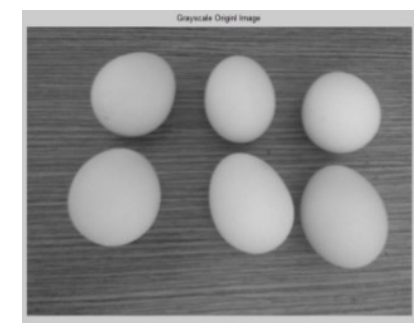

(c)

Gambar 2. Grayscale format .JPG (a) Citra Asli (b) Citra Kompresi Wavelet (c) Citra Grayscale dari Citra Asli

Proses pengubahan citra warna (RGB) menjadi citra grayscale dilakukan dengan menggunakan padding haar agar baris dan kolom citra dapat dibagi 8. Sehingga dengan menggunakan padding akan didapatkan ukuran (disk) citra yang lebih kecil. Dalam gambar citra terlihat sama, tapi ukuran citra yang dihasilkan berbeda. Ukuran citra asli yaitu $125 \mathrm{~KB}$, setelah dilakukan padding dengan matrik haar 8x8 seperti di atas kemudian dilakukan konversi menjadi grascale (Gambar 2.(a)) memiliki ukuran $113 \mathrm{~KB}$ dan citra kompresi dengan metode wavelet (Gambar 2.(b)) memiliki ukuran $53.8 \mathrm{~KB}$ dan dengan nilai dimensi yang sama yaitu 1280x960 (pixels).

Haar wavelet menggunakan metode untuk memanipulasi matriks disebut averaging dan differencing. Seluruh baris dari matriks gambar diambil, kemudian melakukan averaging dan differencing. Matriks Haar digunakan karena metode ini mampu memberikan hasil yang cepat dan efisien dalam pemakaian memori [17].

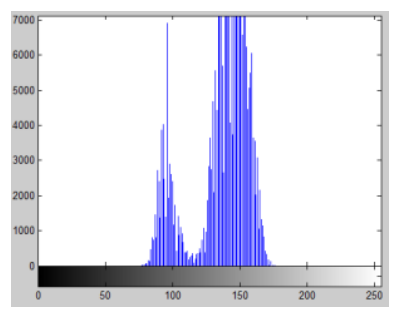

(a)

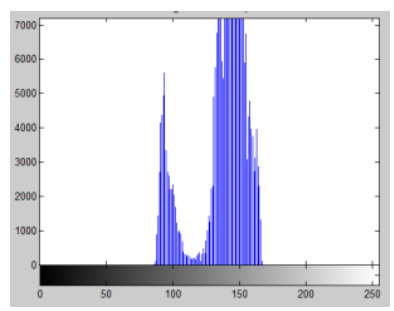

(b)

Gambar 3. Histogram Citra Grayscale (a) Citra Asli (b) Citra Kompresi Wavelet

Berdasarkan Gambar 3, dapat terlihat bahwa histogram citra memiliki komposisi nilai yang berbeda, akan tetapi memiliki bentuk pola yang sama untuk citra grayscale yang asli dengan citra kompresinya. Kompresi citra digital adalah salah satu metode yang yang digunakan dalam meminimalisir adanya redundansi [18]. Kompresi wavelet dapat dilakukan dengan menggunakan transformasi wavelet DWT [19]. Transformasi DWT digunakan untuk mentransformasi citra menjadi beberapa koefisien wavelet. Kompresi dilakukan untuk mendapatkan ukuran citra (disk) lebih kecil, 
sehinggan Gambar 3 menunjukkan bahwa citra grayscale dari citra asli memberikan penyebaran nilai intensitas yang lebih luas jika dibandingkan dengan citra kompresi wavelet. Walaupun ukuran penyimpanan citra hasil kompresi memberikan nilai yang lebih kecil, akan tetapi memiliki ukuran pixel yang sama. Sehingga dalam representasi histogram memberikan nilai yang mendekati dengan bentuk yang sama dan penyebaran intensitas yang berbeda (terlihat pada Gambar 3)

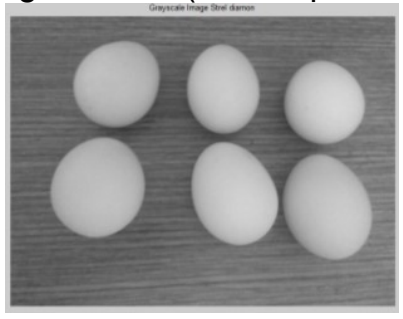

Gambar 4. Citra Grayscale dengan Strel Diamond

Citra grayscale pada masing-masing citra yaitu citra asli (original), citra asli (padding haar) dan citra hasil kompresi wavelet (dengan padding haar) memberikan hasil proses dengan menggunakan strel diamond. Gambar 4 menunjukan bahwa citra grayscale terdapat banyak jajar genjang, dimana strel diamond digunakan untuk mereduksi noise.

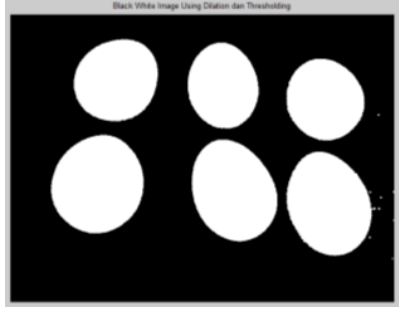

Gambar 5. Citra Hitam Putih Menggunakan Metode Dilasi dan Thresholding

Gambar 5 menunjukan bahwa citra grayscale yang dilakukan konversi menjadi citra hitam putih. Dilasi bertujuan untuk memperbesar ukuran segmen pada lapisan di sekitar obyek sehingga akan terlihat jelas objek yang diidentifikasi. Pada Gambar 5 terlihat pada bagian pojok kanan bawah masih terdapat bintik-bintik sehingga perlu dilakukan proses opening (menjadi Gambar 6).

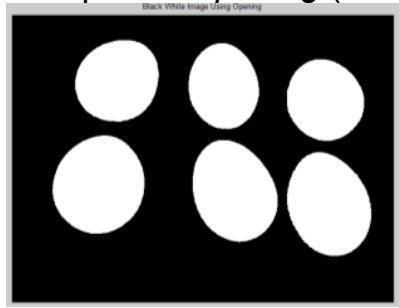

Gambar 6. Citra Hitam Putih Dilakukan Proses Opening

Proses opening dilakukan untuk memperhalus batas objek, memperhalus objek dan menghilangkan noise. Sehingga dihasilkan citra telur yang mampu memisahkan objek dengan background tanpa noise. Proses opening dilakukan mempermudah dalam segmentasi dan pelabelan sehingga diperoleh hasil Gambar 7.

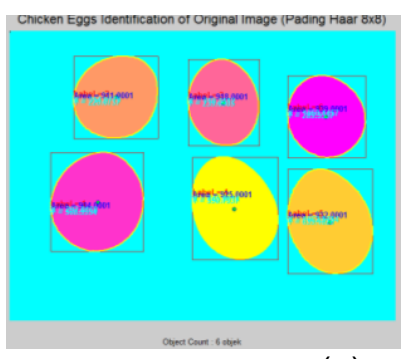

(a)

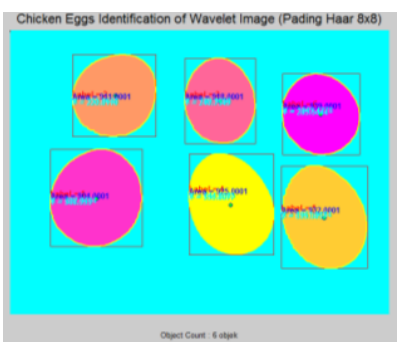

(b)

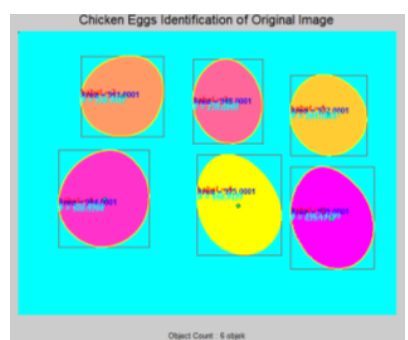

(c)

Gambar 7. Hasil Segmentasi dan Pelabelan (a) Citra Asli (Padding Haar), (b) Citra Kompresi Wavelet (Padding Haar), (c) Citra Asli (Original)

Gambar 7 menunjukan hasil proses segmentasi dan pelabelan, dan penghitungan objek (telur ayam), pada Gambar 7.(a) citra asli dilakukan proses padding haar untuk mengurangi ukuran penyimpanan dan Gambar 7.(b) citra kompresi menggunakan metode wavelet dan dikenai proses padding haar juga sehingga didapatkan ukuran penyimpanan yang lebih kecil dibandingkan dengan Gambar 7.(b). Sedangkan pada Gambar 7.(c) merupakan gambar hasi dari citra asli (original) tanpa 
ILKOM Jurnal Ilmiah Volume 8 Nomor 3 (Desember 2016)

padding haar dan kompresi. Berdasarkan pada Gambar 7 maka didapatkan jumlah objek telur dari citra yang diproses, luas area dan titik centroid $(\mathrm{X}$ dan $\mathrm{Y})$ terlihat pada Tabel 1.

Tabel 1. Hasil Penentuan Titik Centroid dan Luas Area dan Perhitungan Jumlah Objek

\begin{tabular}{|c|c|c|c|c|}
\hline \multirow{2}{*}{ Citra } & \multirow{2}{*}{$\begin{array}{c}\text { Jumlah } \\
\text { Objek }\end{array}$} & \multirow{2}{*}{ Luas Area } & \multicolumn{2}{|c|}{ Titik Centroid } \\
\hline & & & Terhadap X & Terhadap $Y$ \\
\hline \multirow{6}{*}{ Citra Asli (Original); } & \multirow{6}{*}{6} & 904,0001 & 292.9704 & 568.995 \\
\hline & & 911,0001 & 355.0638 & 220.8116 \\
\hline & & 918,0001 & 709.9058 & 240.7549 \\
\hline & & 925,0001 & 744,8585 & 590.8077 \\
\hline & & 932,0001 & 1061.9184 & 635.0897 \\
\hline & & 939,0001 & 1049.4278 & 285.5444 \\
\hline \multirow{6}{*}{$\begin{array}{l}\text { Citra Asli dengan } \\
\text { padding Haar; }\end{array}$} & \multirow{6}{*}{6} & 904,0001 & 292.9704 & 568.995 \\
\hline & & 911,0001 & 355.0638 & 220.8116 \\
\hline & & 918,0001 & 709.9058 & 240.7549 \\
\hline & & 925,0001 & 744,8585 & 590.8077 \\
\hline & & 932,0001 & 1061.9184 & 635.0897 \\
\hline & & 939,0001 & 1049.4278 & 285.5444 \\
\hline \multirow{6}{*}{$\begin{array}{l}\text { Citra Kompresi } \\
\text { Wavelet dan } \\
\text { Padding Haar }\end{array}$} & \multirow{6}{*}{6} & 904,0001 & 292.9704 & 568.995 \\
\hline & & 911,0001 & 355.0638 & 220.8116 \\
\hline & & 918,0001 & 709.9058 & 240.7549 \\
\hline & & 925,0001 & 744,8585 & 590.8077 \\
\hline & & 932,0001 & 1061.9184 & 635.0897 \\
\hline & & 939,0001 & 1049.4278 & 285.5444 \\
\hline
\end{tabular}

Berdasarkan pada Tabel 1 maka diperoleh bahwa citra asli (original), citra asli dengan padding haar dan citra kompresi wavelet dan padding haar menunjukkan hasil yang sama untuk perhitungan titik centroid (X maupun $Y$ ), perhitungan objek, dan Luas area pada setiap objek yang terekam dalam citra tersebut. Sehingga diperoleh tabel perbandingan berikut (Tabel 2) dan dapat dirasiokan dalam bentuk grafik (Gambar 8).

Tabel 2. Perbandingan Citra Asli dan Citra Kompresi Wavelet

\begin{tabular}{|c|c|c|c|c|c|c|}
\hline \multirow{2}{*}{\multicolumn{2}{|c|}{ Citra }} & \multirow{2}{*}{$\begin{array}{c}\text { Jumlah } \\
\text { Objek }\end{array}$} & \multirow{2}{*}{ Luas Area } & \multicolumn{2}{|c|}{ Titik Centroid } & \multirow{2}{*}{ Size on disk } \\
\hline & & & & Terhadap X & Terhadap Y & \\
\hline a. & Citra Asli & Sama & Sama & Sama & Sama & Besar \\
\hline b. & $\begin{array}{l}\text { Citra Asli } \\
\text { dengan } \\
\text { padding } \\
\text { Haar; }\end{array}$ & Sama & Sama & Sama & Sama & $\begin{array}{l}\text { Lebih Kecil dari } \\
\text { pada Citra Asli } \\
\text { (Padding Haar) }\end{array}$ \\
\hline c. & $\begin{array}{l}\text { Citra } \\
\text { Kompresi } \\
\text { (Padding } \\
\text { Haar) }\end{array}$ & Sama & Sama & Sama & Sama & $\begin{array}{l}\text { Lebih Kecil dari } \\
\text { pada Citra Asli } \\
\text { (Padding Haar) }\end{array}$ \\
\hline
\end{tabular}

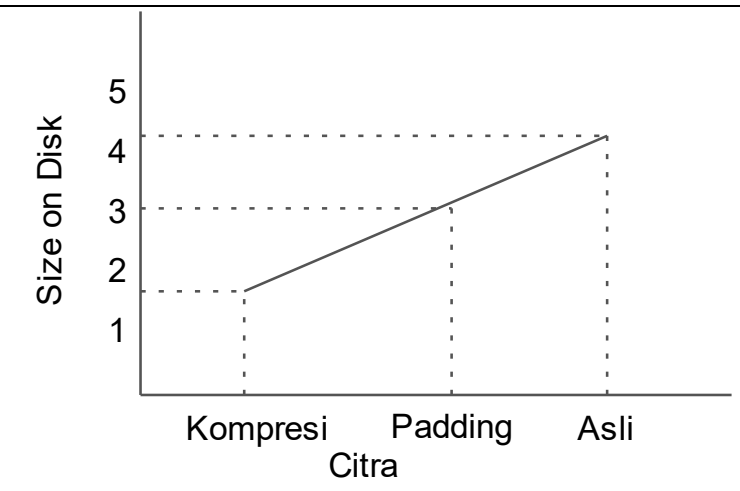

Gambar 8. Grafik Perbandingan Ukuran Penyimpanan Citra 


\section{Kesimpulan}

Berdasarkan pada proses preprocessing sampai dengan hasil penentuaan objek maka diperoleh kesimpulan bahwa proses segmentasi pada citra asli dan kompresi memberikan hasil yang sama. Dari semua proses yang membedakan dari citra asli dan citra kompresi menggunakan metode wavelet adalah pada ukuran penyimpanan (size on disk). Berdasarkan pada Tabel 2 maka dapat disimpulkan bahwa dengan kompresi akan menghemat penyimpanan (disk) dan dengan citra kompresi memberikan hasil segmentasi dan penentuan objek yang sama dengan citra aslinya. Hasil menunjukkan 100\% kesamaan pada proses perhitungan objek, luas area, dan penentuan titik centroid.

\section{Daftar Pustaka}

[1] Trisnaningtyas, Puspa Rizky. Maimunah, Klasifikasi Mutu Telur Berdasarkan Kebersihan Kerabang Telur Menggunakan K-Nearest Neighbor, Konferensi Nasional Informatika (KNIF), (2015).

[2] Nurhayati, Oky Dwi, Sistem Analisis Tekstur Secara Statistik Orde Pertama Untuk Mengenali Jenis Telur Ayam Biasa dan Telur Ayam Omega-3, Jurnal Sistem Komputer, Vol. 5, No. 2, 7982. ISSN: 2087-4685, e-ISSN: 2252-3456, (2015).

[3] Wijaya, Tria Adhi, Yudi, Prayudi, Implementasi Visi Komputer Dan Segmentasi Citra Untuk Klasifikasi Bobot Telur Ayam Ras, Seminar Nasional Aplikasi Teknologi Informasi 2010, G1G5, ISSN: 1907-5022, (2010).

[4] Khabibulloh, M. Arif, Kusumawardhani, Apriani, Pratama, Detak Yan, Rancang Bangun Sistem Deteksi Embrio pada Telur Menggunakan Webcame, Jurnal Teknik Pomits, Vol. 1, No. 1, 1-6 (2012).

[5] Liu Hai-ling, Cai Jian-rong, Sun Li, Yuan Lei-ming, \& Liu Meng-lei, Research on the Discrimination of Hatching Eggs Activity Based on Thermal Imaging: A Food Nondestructive Testing Practice, International Journal of Smart Home. Vol. 10, No. 2, 175-186, (2016).

[6] Chern-Sheng Lin, Po Ting Yeh, Der-Chin Chen, Yih-Chih Chiou, Chi-Hung Lee, The Identification and Filtering of Fertilized Eggs with a Thermal Imaging System, Computers and Electronics in Agriculture 91 (2013), 94-105, (2012).

[7] L. Liu, M. O. Ngadi, Detecting Fertility and Early Embryo Development of Chicken Eggs Using Near-Infrared Hyperspectral Imaging, Springer, Food Bioprocess Technol (2013) 6:25032513, (2012).

[8] TRIDINEWS, 5 Fakta tentang Thermal Imaging, http://www.news.tridinamika.com, post 24/11/2014

[9] Ruslianto, Ikhwan, Klasifikasi Telur Ayam Dan Telur Burung Puyuh Menggunakan Metode Connected Component Analysis, Jurnal IImiah SISFOTENIKA, Vol. 3, No. 1, 41-50, (2013).

[10] Utami, Yustina Retno Arum, Pengenalan Telur Berdasarkan Karakteristik Warna Citra, Jurnal IImiah SINUS, Vol. 7, No.2, 1-14, ISSN: 1693-1173, (2009).

[11] Andono, Pulung Nurtantio, Konsep Pengolahan Citra Digital, Ed. 1. Yogyakarta: Andi, (2015).

[12] Ahmad, U., Pengolahan Citra Digital \& Teknik Pemrogramannya, ed. 1, Yogyakarta: Graha IImu, 2005.

[13] http://www.metode-algoritma.com/2015/07/metode-penyetaraan-histogram.html

[14] Pramana, C.J., Implementasi Metode Thresholding dan Metode Regionprops untuk Mendeteksi Marka Jalan Secara Live Video, Jurnal Universitas Dian Nuswantoro Semarang, 2014.

[15] Hermansyah D., Kompresi Citra Menggunakan Metode Wavelet Embedded Zerothree Of Coefficient Wavelet (EZW), http://eprints.dinus.ac.id/16574/1/jurnal_15563.pdf, access 20 November 2016

[16] Sunardi, Yudhana, A., Saifullah, S., Thermal Imaging Untuk Identifikasi Telur, Prosiding Konferensi Nasional Ke-4, Asosiasi Program Pascasarjana Perguruan Tinggi Muhammadiyah (APPPTM), hlm. 152-157, 2015.

[17] Raviraj, P., Sanavullah, M.Y., The Modified 2D-Haar Wavelet Transformation in Image Compression, Middle-East Journal of Scientific Research 2 (2): 73-78, 2007.

[18] Sugiharto, A., Harjoko A., Kompresi Citra Digital Dengan Fraktal Sebagai Teknlk Kompresi Alternatif, Prosiding Seminar Nasional SPMIPA 2006, Bagian II. Ilmu Komputer, hlm. 1-7.

[19] Antonini, M., Barlaud, M., Images Coding Using Wavelet Transform, IEEE Trans. On Image Processing, Vol. 1, No. 2, pp. $205-220,1992$ 